\title{
Beach Community-Designed System To Ameliorate Water Quality Deterioration in Catchments of Lake Victoria
}

\author{
Fredrick Jones Muyodi ${ }^{\mathrm{a}, *}$ and Raphael Kapiyo ${ }^{\mathrm{b}}$ \\ ${ }^{a}$ Department of Biological Sciences, School of Biosciences, Makerere University, P.O. Box 7062, Kampala, Uganda \\ ${ }^{b}$ School of Environment \& Earth Sciences, Maseno University, P.O. Box Private Bag, Maseno, Kenya
}

\begin{abstract}
Water quality and socio-economic status of beach communities was studied in the Thruston Bay catchments of Lake Victoria. The major aim of the study was to establish the relation between water quality and socio-economic status of the communities in the study sites and come up with a sustainable community-designed system to control water quality degradation. Physico-chemical characteristics of water were determined on-site while total and fecal coliforms were determined in the laboratory using standard methods. The most probable number (MPN) technique was used to determine the total coliforms (TC) while the fecal coliform (FC) Test was used for testing the presence or absence of fecal coliforms. All sites tested positive for total and fecal coliforms. Borehole water had the highest MPN values followed by $10 \mathrm{~m}$ site. To compliment on the water quality data collected, a socio-economic status study of beach communities was conducted using questionnaires, structured interviews, focus group discussions and observations. Data and information on the demographic characteristics, asset ownership, livelihood activities, social facilities, health and sanitation, communication and outreach, solid waste and fisheries management and Beach Management Units (BMU) establishments, among others, was collected. A method in form of a model was designed using a participatory approach by the beach communities to be used to ameliorate lakeshore degradation by the communities in collaboration with other stakeholders.
\end{abstract}

Keywords: Buluba, fisher communities, lake victoria, socio-economic, thruston bay, water quality.

\section{INTRODUCTION}

Lake Victoria is the world's second largest freshwater lake by area and the largest in Africa. With a surface area of $68,800 \mathrm{~km}^{2}$, it fills a shallow depression in a great plateau at $1,134 \mathrm{~m}$ between the eastern and western rift valleys, holding $2,760 \mathrm{~km}^{3}$ of water at an average depth of $40 \mathrm{~m}$ and maximum depth of $84 \mathrm{~m}$. This volume of water takes 100 years to be replaced by inflows. The temperature range in the lake is narrow and warm with a mean temperature of $25^{\circ} \mathrm{C}$. The shoreline is about $3,500 \mathrm{~km}$ long and convoluted, enclosing innumerable small, shallow bays and inlets, many of which include swamps and wetlands. The lake is shared between Kenya 6\%, Uganda 43\% and Tanzania 51\%. Rwanda and Burundi also share the lake's catchment. The lake is drained at a rate of about $600 \mathrm{~m}^{3} \mathrm{~s}^{-1}$ at Jinja on the northern shore into the Victoria Nile which flows northward via Lake Albert and White Nile into the Mediterranean Sea. There are a number of coastal towns such as Kisumu (Kenya), Entebbe (Uganda), Bukoba, Mwanza and Musoma (Tanzania), connected with each other by ship routes [1].

In the 1980s, a shift in Lake Victoria's fauna became noticeable [2] although the origins of that shift began much

*Address correspondence to this author at the Department of Biological Sciences, School of Biosciences, Makerere University, P.O. Box 7062, Kampala, Uganda; Tel: +256414531902; Fax: +256 414530134;

E-mail: fmuyodi@zoology.mak.ac.ug earlier [3]. The bottom waters of the lake appeared to be devoid of oxygen and fish life. On the other hand, the lake was chocked with algae, about 5 to 10 times more than in the early 1960s [4], suggesting eutrophication. Nutrient inputs have increased at least two to three-folds since the turn of the century [5].

Lake Victoria offers the riparian communities a large number of extremely important environmental services. More than 30 million people in 5 countries share and affect the resources of the lake basin. Harmful activities in the catchment ultimately have an effect on the lake, and thus affect the livelihoods of people; these developments are already disrupting the current fishing activities in the area and grossly affecting the livelihood of the local people.

The lake provides both renewable and non-renewable resources. Effective and efficient management of the resource base is essential for economic and social welfare and its environmental quality. Over the past four decades or so, the lake has come under increasing and considerable pressure from a variety of interlinked human activities, such as, overfishing, species introductions, industrial pollution, eutrophication, and sedimentation $[6,7]$.

The lake water quality problems are primarily driven by land based activities and secondarily from lake-based activities. These are a result of increased population pressure and the associated human activity. It was observed that populations of urban areas along the lake were growing at an esti- 


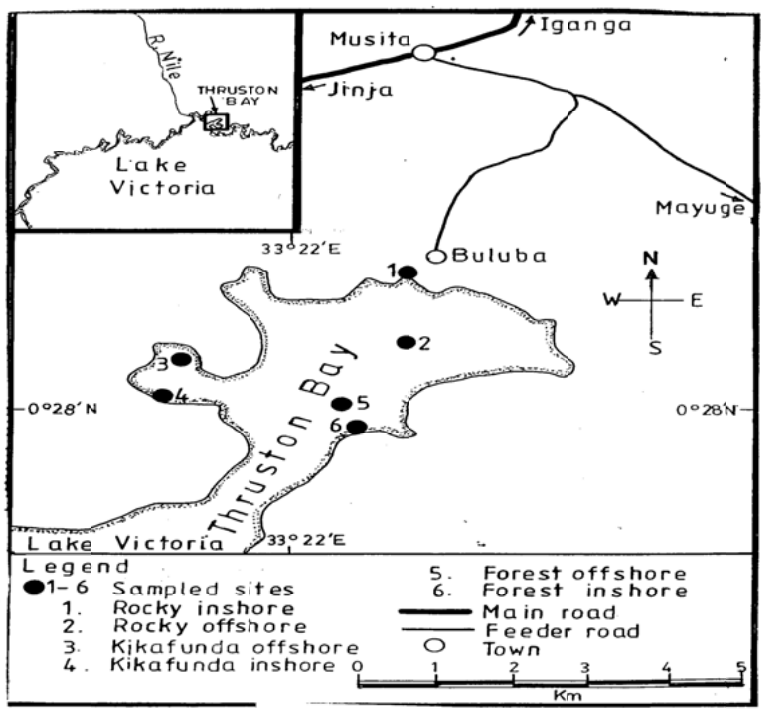

Fig. (1). Location map of Lake Victoria, showing study site (1) in Thruston Bay, Uganda [9].

mated $6 \%$ per annum and rural areas near the lake shore were experiencing in-migration which was causing faster growth of their populations [8].

There was need therefore, to study the link between the deteriorating environmental quality and the current socioeconomic status of fisher communities in the catchments of Lake Victoria. The study established the impact of water quality on the socio-economic well-being of the riparian communities and developed a method that involves and motivates the fisher-folk communities in the reduction of water quality deterioration.

The paper presents findings on environmental quality and the socio-economic status of the fisher communities, suggesting measures for lake ecosystem services restoration, sustainable management of the lake ecosystem and improvement of the fishers' livelihoods. The paper also presents a model that has been developed by the fisher-folk communities to be piloted as an integrated system for water quality, health and sanitation management at the beaches.

\section{MATERIAL AND METHODOLOGY}

\subsection{Study Area}

The study was conducted in the northern part of the Uganda catchment of Lake Victoria. The study sites were located in the Thruston bay (Fig. 1). Thruston Bay has an area of about 1650 ha and is located in the northeastern part of the Napoleon Gulf. The Bay has an average and maximum depth of $5 \mathrm{~m}$ and $11 \mathrm{~m}$, respectively. In contrast to other nearby bays, such as, Fielding and Hannington, Thruston Bay has a large littoral wetland dominated by macrophytes Cyperus papyrus (papyrus), Phragmites mauritianus (reeds), Typha domingensis (cattails), Vossia cuspidata (hippo grass) and Eichhornia crassipes (water hyacinth). Three sampling sites were selected along a transect line at the landing beach from the shoreline towards the open waters. Site 1 $\left(033^{\circ} 23^{\prime} 21.0^{\prime \prime} \mathrm{E}\right.$ and $\left.00^{\circ} 29^{\prime} 11.4^{\prime \prime} \mathrm{N}\right)$ was $10 \mathrm{~m}$ from the shore-line, Site $2\left(033^{\circ} 23^{\prime} 21.8^{\prime}\right.$ ' $\mathrm{E}$ and $00^{\circ} 29^{\prime} 07.4^{\prime}$ 'N $)$ was $50 \mathrm{~m}$ from Site 1 while Site $3\left(033^{\circ} 23^{\prime} 19.5^{\prime}, \mathrm{E}\right.$ and $00^{\circ} 29^{\prime} 16.6^{\prime \prime} \mathrm{N}$ ) was the furthest site at $100 \mathrm{~m}$ from Site 2. A community borehole $\left(033^{\circ} 23^{\prime} 22.6^{\prime \prime} \mathrm{E}\right.$ and $00^{\circ} 29^{\prime} 01.7^{\prime}$ ' $\left.\mathrm{N}\right)$, $25 \mathrm{~m}$ away from the shore-line was also sampled for its water quality in order to compare with the lake water quality.

\subsection{Water Quality and Bacteriological Analysis}

Field sampling in the three selected sites started in August 2011 and continued fortnightly until end of November 2011. In-situ water measurements of temperature, dissolved oxygen (DO) (Probe model YSI 200), conductivity, $\mathrm{pH}$ and total dissolved solids (TDS) were measured using a WagTech multi-probe (Model Wag-WE30250, supplied by WagTech Company, United Kingdom). Raw water samples for bacteriological analysis were collected in duplicates from the selected study sites in previously sterilized sample bottles, caped and stored in an ice box until they were analyzed in the laboratory within $6 \mathrm{~h}$ from sampling time.

\subsubsection{Total Coliform Determination Using the Most Probable Number (MPN) Method}

Five dilution test tubes were dispensed with $9 \mathrm{~mL}$ of sterile distilled water. One (1) $\mathrm{mL}$ of sample was pipetted into the first test tube and serial dilutions prepared as follows: from the first test tube, $1 \mathrm{~mL}$ of thoroughly mixed solution was pipetted into the second test tube and the procedure repeated for all the five tubes. Dilutions for the other samples were also prepared using the same procedures as described in standard methods [10]. Lactose Broth (HiMedia laboratories, Pvt. Ltd, Mumbai India) was used for the MPN growth experiments. The procedures as described by the manufacturer were as follows: $13 \mathrm{~g}$ of dehydrated media were suspended in $1 \mathrm{~L}$ of distilled water in a conical flask. The solution was heated to allow uniform mixing for $1 \mathrm{~min}$. Nine (9) $\mathrm{mL}$ of the media were then dispensed in test tubes containing inverted Durham tubes, covered with cotton wool. These were then autoclaved at $121{ }^{\circ} \mathrm{C}$ for $15 \mathrm{~min}$. To each of the MPN media tubes (after cooling), $1 \mathrm{~mL}$ of sample or dilution series (from raw sample and diluted sample from the dilution tubes) was added, labeled and then covered/caped with cotton wool. Three un-inoculated tubes with media were subjected to similar conditions and acted as control tubes. All the tubes were then incubated at $35^{\circ} \mathrm{C}\left( \pm 2{ }^{\circ} \mathrm{C}\right)$ for $24 \mathrm{~h}$.

\subsubsection{Fecal Coliforms (FC) Presence Determination}

MacConkey Agar (Prondisa Laboratories, Conda, S.A.) was used for the culture of fecal coliforms (FC). Fifty (50) g of the media were suspended in $1 \mathrm{~L}$ of distilled water, mixed well and heated for $1 \mathrm{~min}$ to ensure uniform mixing. The media was autoclaved at $121{ }^{\circ} \mathrm{C}$ for $15 \mathrm{~min}$, left to cool to 45 ${ }^{\circ} \mathrm{C}$, dispensed $\sim 10 \mathrm{~mL}$ of media into sterile Petri-dishes and left for a few minutes to solidify. Solidified plates were inverted to avoid excessive moisture on the surface of medium. Positive tubes from MPN experiment were considered for sub-culturing as follows: using a flamed but cooled wire loop, a film from the positive tubes was stripped onto solidified MacConkey plates. The inoculated plates were then incubated at $44.5{ }^{\circ} \mathrm{C}\left( \pm 2{ }^{\circ} \mathrm{C}\right)$ for $24 \mathrm{~h}$. 


\subsubsection{Observation, Recording and Data Analysis}

From the MPN tubes, positive tubes for TC were considered for computation of MPN. These were the tubes that had developed pockets of gas in the inverted Durham vials plus acid production. In cases where the tubes were not positive, the results were read as zero (0). The corresponding MPN values were read off in the MPN tables as presented in APHA [10] and the number of organisms per dilution was calculated using the middle dilution and expressed as MPN $100 \mathrm{~mL}^{-1}$ of original sample. For fecal coliforms (FC) determination of presence or absence, the plates that had purple to deep red colonies and slightly shinny and round, were recorded as positive (+ve) for fecal coliforms. This gave evidence for presence of fecal coliforms (FC) in the source water. Negative (-ve) plates had no growth on them and the same was true for the control plates. The MPN results were then statistically analyzed using GraphPad Prism statistical software (GraphPad Prism 5 for Windows Version 5.04, 1992 - 2010 GraphPad Software Inc. USA) to establish whether there were any significant differences between sampling sites in terms of coliform organisms.

\subsection{Socio-economic Study}

The study was undertaken among the community members including boat owners and crew members who go out fishing in Thruston Bay catchment. The study employed a three stage approach that included document review, field investigations and data analysis. During the literature review, gaps were identified in socio-economic knowledge about fishing communities [11]. Field investigations were conducted at the beach through structured interviews, questionnaires, focus group discussions and observations. The socioeconomic study was aimed at providing demographic information on the different categories of stakeholders around the beach and who were dependent on the lake fisheries and covered the following parameters among others: social and educational status, residency status, assets owned and their location, fishing activities undertaken, distribution of income between boat owners and the crew, level of involvement in fishery activities, health status and welfare indicators.

\subsubsection{Socio-economic Data Collection and Analysis}

The study covered a range of fishery and non fishery enterprises such as farming and animal rearing as well as sanitation and health issues. It targeted boat owners, fish traders and processors, fishing crew, Beach Management Unit (BMU) committee members. Other stakeholders included boat repairers, shop keepers, farmers and herdsmen. Both qualitative and quantitative methods were used. Data was collected using a questionnaire and a total of 72 respondents were covered at the beach, in addition to direct observations. Interviews were conducted with four stakeholder groups and the target sample for each group was 20. Respondents were selected at random on arrival. Data collected was entered into a Statistical Package for Social Scientist (SPSS) for analysis using SPSS Version 16. Output summaries were presented as frequencies and figures while for numerical data, means, minimums, maximums and standard deviations ( $\mathrm{SD}$ as \pm ) were computed. The content analysis method was used to analyse the qualitative information collected. Focus

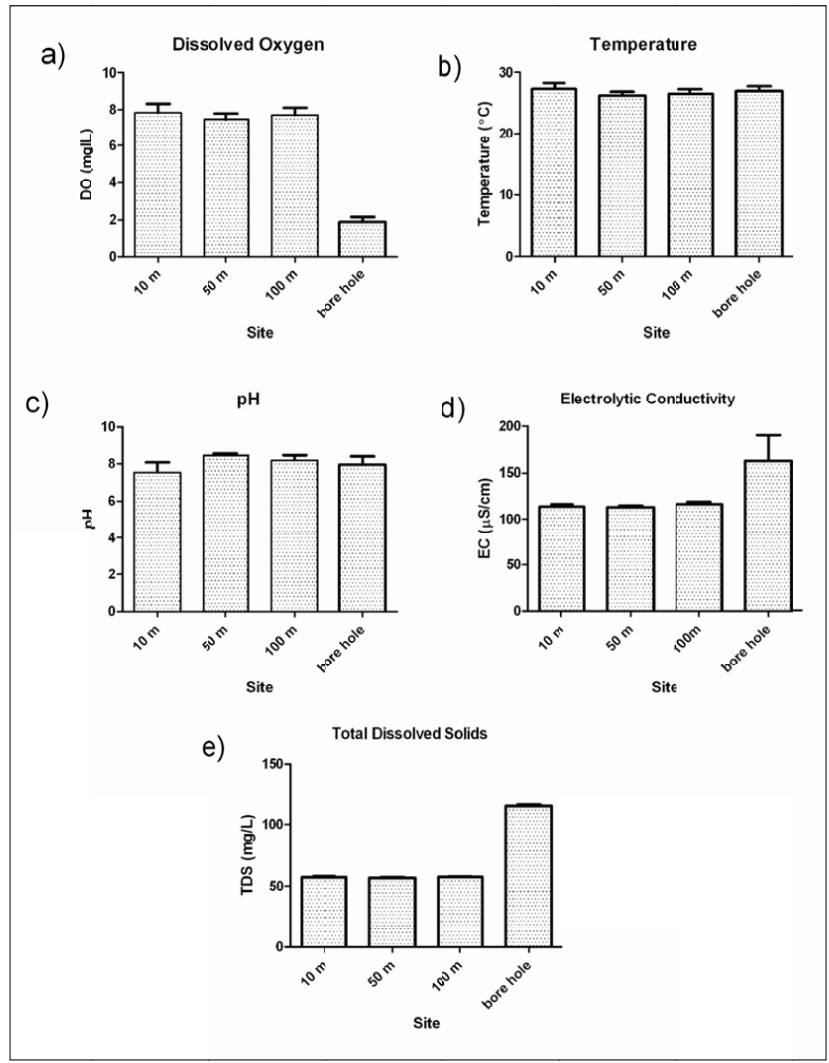

Fig. (2). Mean values of water quality parameters in the study sites of Thruston bay at the different stations a) Dissolved oxygen (DO), b) Temperature, c) $\mathrm{pH}$, d) Electrolytic Conductivity (EC), and e) Total Dissolved Solids (TDS).

group discussions were also held with the selected stakeholder groups. The discussions deliberately involved women and youths who were heavily involved in fishery activities as a special group in order to capture their views [12].

\section{RESULTS AND DISCUSSION}

\subsection{Water Quality Parameters}

Water quality parameters varied from site to site and are presented in Fig. (2). Water temperature has increased compared to that measured in earlier studies [13, 14]. This may be attributed to removal of vegetation at the inshore sites. Dissolved oxygen (DO) values were higher in the 10-m, 50 $\mathrm{m}$ and $100-\mathrm{m}$ sites probably due to mixing as these sites had macrophytes and stones on which water mixed. Between 1996 and 1998, about 800 ha of Thruston Bay was covered with thick mats of water hyacinth which collapsed and sank to the bottom of the bay, following impact of biological control measures and other environmental factors. Between 1999 and 2000, dissolved oxygen (DO) levels were between 2.5-5.5 $\mathrm{mg} \mathrm{L}^{-1}$ [15]. In December 2000, surface water quality parameters in the shallow $(<4 \mathrm{~m})$ littoral wetland habitats of the bay were: DO, $4.9 \mathrm{mg} \mathrm{L}^{-1}$; electrolytic conductivity (EC), $110.7 \mu \mathrm{S} \mathrm{cm}^{-1}$; total phosphorus (TP), $30.6 \mu \mathrm{g} \mathrm{L}^{-1}$; ammonia, $0.5 \mu \mathrm{g} \mathrm{L}^{-1}$; and chlorophyll- $a, 64.3 \mu \mathrm{g} \mathrm{L} \mathrm{L}^{-1}$ [15]. Borehole water had least levels of DO probably due to limited oxygen availability and water mixing in the aquifer [1, 


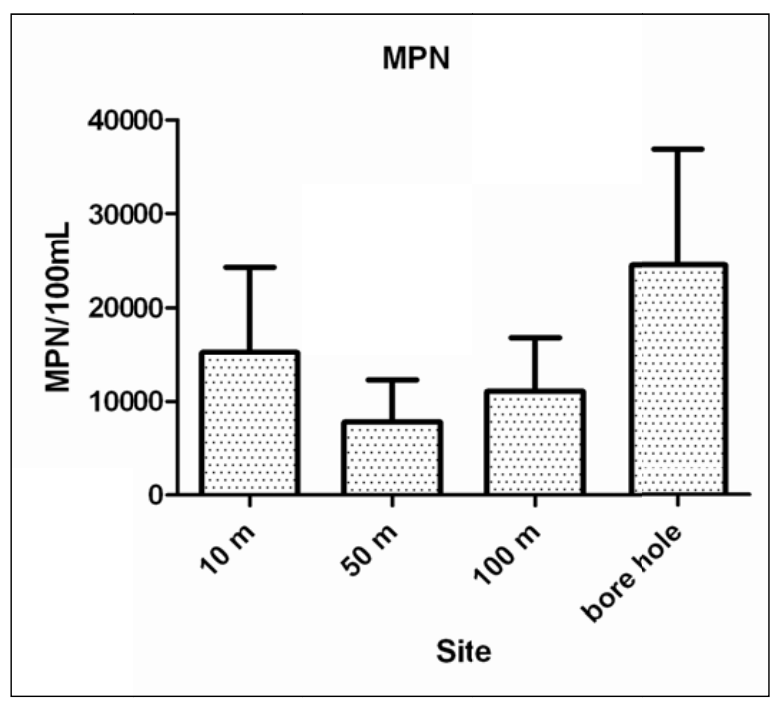

Fig. (3). Mean values (MPN $100 \mathrm{~mL}^{-1}$ ) of Total Coliforms (TC) in the study sites of Thruston bay at the different stations.

16]. The difference in levels of DO among lake and borehole sites was very significant $(\mathrm{p}<0.0001)$. Temperature showed very little variation across sites and the difference was not significant between lake and borehole sites $(\mathrm{p}=0.3788)$. This pattern could be linked to the $85 \%$ cloud cover during sampling. $\mathrm{pH}$ values for $10 \mathrm{~m}$ site was slightly lower than the other three sites, although difference was not significant $(\mathrm{p}=0.3869)$. This slight difference could be due to human activities along the shoreline.

Borehole water had the highest values of electrolytic conductivity (EC) and the difference was significant among sites $(p=0.031)$ and extremely significant between the lake water and borehole water $(\mathrm{p}<0.0030)$. Total dissolved solids (TDS) were also higher at the borehole and the difference was extremely significant $(\mathrm{p}<0.0001)$. As ground water sips through the rocks, it carries along some fine materials and some chemical elements dissolved in it unlike the lake sites that are exposed to mixing and dilution by the water waves [13].

\subsection{Bacteriological Water Quality}

All sampling sites studied showed positive results for total coliforms (TC) and fecal coliforms (FC) suggesting presence of the coliform bacteria in water. The borehole water had the highest value of Most Probable Number (MPN) followed by the $10 \mathrm{~m}$ site (Fig. 3). The difference between the lake and the borehole sites was significant $(\mathrm{p}=0.0282)$. This high MPN could be attributed to nearby sanitary facilities (Pit latrines) to the bore hole. Other activities at the shoreline included washing clothes and cars, bathing and ritual cleansing, which could be potential sources of fecal contamination. Runoff from residential areas was considered as a potential non-point source for fecal contamination [7].

\subsection{Socio-economic Parameters}

The communities living along the beaches of Lake Victoria had most of their livelihood activities related to fishing

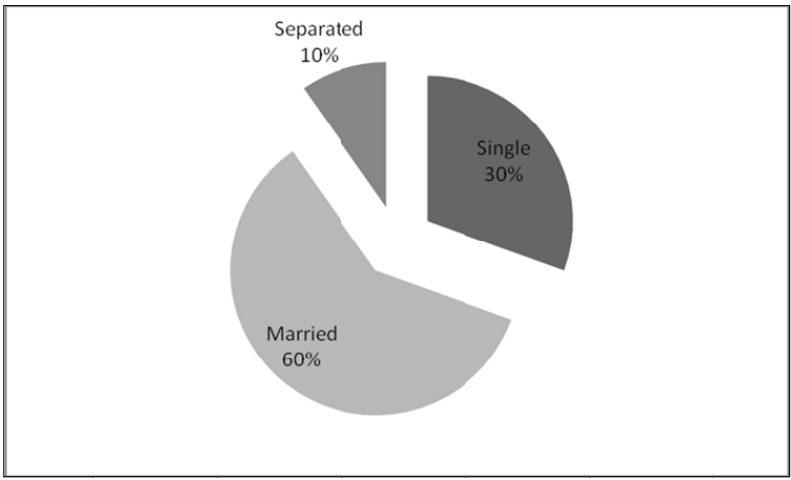

Fig. (4). Marital status of respondents.

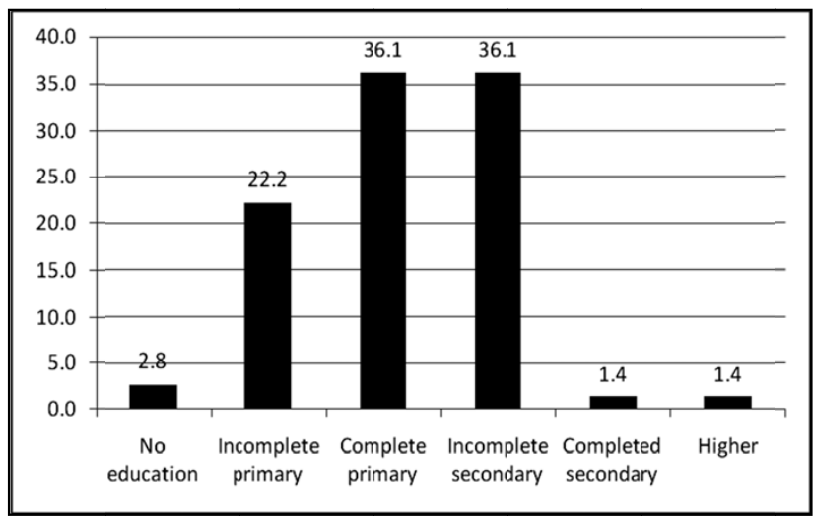

Fig. (5). Highest formal education level of respondents.

[17] while some members were engaged in non-fishing activities, such as, crop and livestock farming and shop keeping, among others.

\subsubsection{Demographic Characteristics}

The number of male $(77.8 \%)$ respondents was rather high than that of the female. The results showed that men had dominated every activity in the fisheries. The majority were also married $(60 \%)$ and this was true across the entire respondent groups (Fig. 4). There was also a large proportion of singles (un-married), which was highest among the crew members $(30.6 \%)$. The largest proportion of respondents was within the economically active age range of 19 to 49 years while the minimum age was 23 years while the maximum was 53 years. Majority lived near the lake within a distance of less than 5 kilometers. Fig. (5) presents the education levels of respondents. The low formal education level at the beach was revealed by the proportion of respondents with no and/or incomplete education (25\%). This could be attributed to the poor educational facilities at the landing site, long distances to nearby schools, low incomes for some fisheries stakeholders and the low demand for education among fishers, who would like their children also to remain in fishery activities [17].

The implication is that entrepreneurship, skills development and resource management would all be constrained, leading to low development and unsustainable fisheries exploitation. The ethnic origin of the respondents was examined. This is presented in Fig. (6) while Table $\mathbf{1}$ presents 


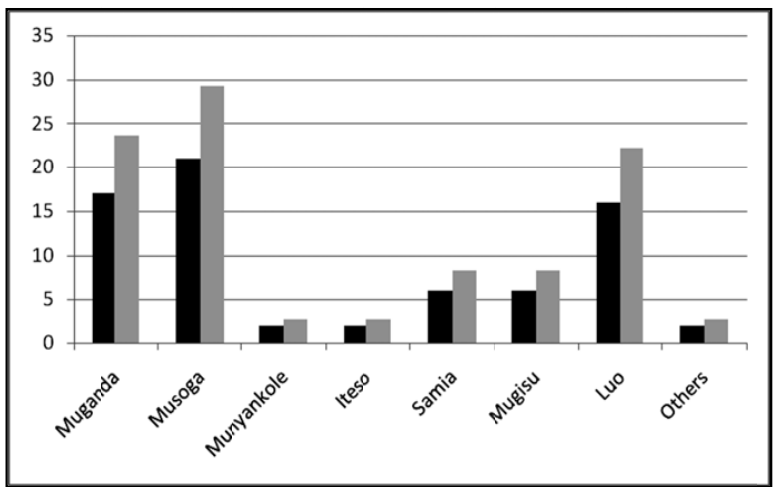

Note: dark bars present frequency and light bars percent.

Fig. (6). Distribution of respondents by tribe.

Table 1. Distribution of Respondents' Birth Places

\begin{tabular}{|l|c|c|}
\hline \multicolumn{1}{|c|}{ Birth Place } & Frequency & Percent \\
\hline \hline Within this village & 12 & 16.7 \\
\hline Another village nearby & 21 & 29.2 \\
\hline This location/ward/sub-county & 3 & 4.2 \\
This district & 2 & 2.8 \\
\hline Other district & 32 & 44.4 \\
\hline Other Country & 2 & 2.8 \\
\hline Total & 72 & 100.0 \\
\hline
\end{tabular}

Table 2. Respondents Livelihood Activities

\begin{tabular}{|l|c|c|}
\hline \multicolumn{1}{|c|}{ Activity } & Frequency & Percent \\
\hline \hline Owns/rent in a boat & 12 & 14.8 \\
\hline Crew member & 30 & 37.0 \\
Trader/Processes fish & 21 & 25.9 \\
\hline Small scale miner & 2 & 2.5 \\
\hline Agriculture & 7 & 8.6 \\
\hline Trader/processes fish /others & 1 & 1.2 \\
\hline Other fisheries related activity & 8 & 9.9 \\
\hline Total & 81 & 100.0 \\
\hline
\end{tabular}

their birth places. The major income generating activities of the stakeholders are presented in Table 2 . Some respondents were involved in more than one activity while the majority were crew members $(37.0 \%)$ followed by those dealing in trading and processing of fish $(25.9 \%)$.

Most of the respondents $(61.1 \%)$ did not own land while $38.9 \%$ owned land. The mean size of the land owned was 1.3 acres while the majority (98\%) could only use it for subsistence crop production. Table 3 presents the usage of land by priority. Rearing of animals (livestock) and birds (poultry) was also reported although on a small scale. Ownership of chicken and ducks contributed $31.7 \%$ followed by goats and sheep at $22 \%$, cattle at $8.5 \%$ while pigs were at $3.7 \%$. Some respondents had difficulties in keeping records. This was
Table 3. Usage of Land by Priority

\begin{tabular}{|l|c|c|}
\hline \multicolumn{1}{|c|}{ Land Usage } & Priority & Percentage \\
\hline \hline Growing of Cash crop & 3 & 0.5 \\
\hline Growing of Food crops & 1 & 98.0 \\
Livestock grazing & 2 & 1.2 \\
Unused land & 4 & 0.3 \\
\hline
\end{tabular}

Table 4. Mean Number of Months for Fishery Activities

\begin{tabular}{|l|c|c|c|c|}
\hline \multicolumn{1}{|c|}{ Question } & N & Minimum & Maximum & Mean \\
\hline \hline $\begin{array}{l}\text { Q34. Fishing employment (wages } \\
\text { and salaries) number of months/ yr }\end{array}$ & 6 & 12 & 12 & 12.00 \\
\hline $\begin{array}{l}\text { Q35. Fish trading and processing } \\
\text { contributing to household income } \\
\text { months/yr }\end{array}$ & 8 & 12 & 12 & 12.00 \\
\hline $\begin{array}{l}\text { Q37. Number of months/yr boat } \\
\text { building and repairing contribute to } \\
\text { household income }\end{array}$ & 1 & 12 & 12 & 12.00 \\
\hline $\begin{array}{l}\text { Q38Number of months/yr non- } \\
\text { fishing employment contribute to } \\
\text { household income }\end{array}$ & 1 & 12 & 12 & 12.00 \\
\hline
\end{tabular}

because most of the animals and birds were kept in their villages of origin rather than at the beaches. Majority of respondents owned bicycles $(32.9 \%)$ and a few owned motorcycles $(1.2 \%)$. However bicycle ownership was mainly among the fish traders and the boat owners. Ownership of motorcycles was predominant among the fish traders who used the motorcycles to transport fish to the different markets. Majority also owned radios $(95.8 \%)$ while a few had television sets (4\%). The large ownership of radios is considered a positive factor in the use of radios in disseminating fisheries and related information.

The study also sought to identify the bedding materials for the respondents. Most of the respondents owned a bed and mattress (62\%), and only $38 \%$ owned only mattresses. The present study revealed that some beds and mattresses were shared between individuals. The implication was that sharing of beddings and mattresses could explain the spread of sexually transmitted diseases (STIs) and HIV/Aids. The fishers' lifestyles at the beach was characterised by alcohol consumption. Regarding fuel used for cooking, the majority of the respondents $(75.7 \%)$ used firewood as their main fuel; others used charcoal $(22.9 \%)$, while a few used paraffin $(1.4 \%)$. This explains the significant deforestation resulting into soil erosion and siltation of the lake. The study also examined the income-earning activities the stakeholders were involved in, for how many months in a year and a ranking of their contribution to household incomes. Table $\mathbf{4}$ presents mean number of months fishers were engaged in fishery activities while Table 5 presents mean number of months fishers were engaged in fishery-related activities.

The availability of social facilities around the beach is presented in Table 6. Majority of respondents (74.2\%) used the main hospital (Buluba Hospital) and the primary school 
Table 5. Mean Number of Months for Fishery-Related Activities

\begin{tabular}{|l|c|c|c|c|}
\hline \multicolumn{1}{|c|}{ Question } & N & Minimum & Maximum & Mean \\
\hline \hline $\begin{array}{l}\text { Q39 Number of months/yr trading } \\
\text { in other food commodities con- } \\
\text { tributes to household income }\end{array}$ & 1 & 12.0 & 12.0 & 12.000 \\
\hline $\begin{array}{l}\text { Q42. Number of months/yr live- } \\
\text { thock farming contributes to } \\
\text { household income }\end{array}$ & 1 & 12 & 12 & 12.00 \\
$\begin{array}{l}\text { Q45. Number of months other } \\
\text { income contributes to household } \\
\text { income }\end{array}$ & 1 & 12 & 12 & 12.00 \\
\hline
\end{tabular}

Table 6. Number of Respondents who Visited Social Facilities

\begin{tabular}{|l|c|c|}
\hline \multicolumn{1}{|c|}{ Facility } & Frequency & Percent \\
\hline \hline Dispensary & 3 & 3.2 \\
\hline Clinic & 2 & 2.2 \\
Hospital & 69 & 74.2 \\
Primary school & 18 & 19.4 \\
\hline Secondary school & 1 & 1.1 \\
\hline Total & 93 & 100.0 \\
\hline
\end{tabular}

in the locality. In terms of status of functioning, $75.3 \%$ reported that the facilities were always functioning while the rest reported occasional functioning $(24.7 \%)$. This was attributed to ownership of the facilities where private facilities were only opened when the owners were present at the beach [18]. The number of members of the households who suffered from the different diseases based on medical records is presented in Table 7. Most respondents suffered from malaria $(\mathrm{N}=69)$, followed by diarrhea $(\mathrm{N}=13)$ and typhoid fever $(\mathrm{N}=12)$. Few respondents reported cases of cholera during the year. This was in agreement with previous studies in the area [7].

\subsubsection{Source of Drinking Water and status of Sanitary Fa- cilities}

The main source of drinking water was the lake $(52.5 \%)$ (Table 8). This exposed the people to the risk of getting infected with water borne diseases. Generally, respondents thought that the water they were using was safe for home consumption $(67.6 \%)$ although a significant percentage of them disagreed $(32.4 \%)$. Majority of the respondents did not have latrines (52.8\%). However, majority of those who did not have latrines used the available public latrines. Most of the latrines were constructed using local materials (poles and grass), were shallow and did not meet the minimum required standards [19]. Others used their neighbors' latrines $(9.8 \%)$ or deposited feaces in the bush $(4.9 \%)$. This was in agreement with earlier studies in beach communities [7]. Majority of the respondents $(90.9 \%)$ believed that the water quality at the fishing site was good although some believed that this was not the case as sometimes algal blooms infested the lake water causing deterioration of water quality.

\subsubsection{Cooking, Lighting, Solid Waste and Fisheries Management}

Majority of respondents used Kerosene lamps (29.5\%) for lighting and cooked in open fires (26.7\%) using firewood. About $24.0 \%$ used Kerosene stoves for cooking while $19.9 \%$ used solar panels for lighting. This had negative implications on lake pollution and environmental degradation as it increased cutting down of trees for wood fuel which increased degradation of the environment [7]. Majority $(93.1 \%)$ of respondents deposited their solid waste in pits; or burned the garbage $(5.6 \%)$ while other methods of solid waste disposal contributed $1.4 \%$. It was observed that most stakeholders believed that it was an individual's responsibility $(66.2 \%, \mathrm{~N}=71)$, others believed that is was the Beach management units (BMU) role $(32.4 \%)$ while others believed it was fishers' responsibility $(1.4 \%)$ to manage solid waste. This implies divergence views over responsibility for waste management, depicting need for awareness creation among the beach communities. The present study examined presence and activity of Fisheries and Environment Officers at the beach to assess extension services support provided to the stakeholders. Majority $(88.7 \%$ and $93.0 \%)$ reported that they were not visited by a Fisheries and an Environment Officer at the beach, respectively. About $11.3 \%$ and $7.0 \%$ respectively, agreed that the Officers visited the landing site. The frequency of visits to the beach communities is presented in Table 9.

Table 10 presents the frequency and percentages of respondents who had ever been received extension services in fisheries and environment while Fig. (7) presents respondents who had ever received information on different areas of fishing and fisheries management.

The study examined the extent to which the stakeholders were organised for the purpose of effectively participating in

Table 7. Mean Number of Persons who Suffered from Diseases in a Household

\begin{tabular}{|c|c|c|c|c|c|}
\hline Question Related to Diseases & $\mathbf{N}$ & Minimum & Maximum & Mean & Std. Deviation \\
\hline Q47. How many members of your household suffered from malaria in the last year? & 69 & 1 & 12 & 1.67 & 1.511 \\
\hline Q50. How many members of your household suffered from convulsions in the last year? & 2 & 1 & 2 & 1.50 & .707 \\
\hline Q51. How many members of your household suffered from HIV/AIDS in the last year? & 1 & 1 & 1 & 1.00 & 0.000 \\
\hline Q52. How many members of your household suffered from diarrhoea in the last year? & 13 & 1 & 12 & 2.08 & 3.040 \\
\hline Q53. How many members of your household suffered from typhoid in the last year? & 12 & 1 & 1 & 1.00 & 0.000 \\
\hline Q54. How many members of your household suffered from cholera in the last year? & 1 & 1 & 1 & 1.00 & 0.000 \\
\hline
\end{tabular}


Table 8. Main Source of Drinking Water and Places For Disposal of Fecal Material

\begin{tabular}{|c|c|c|c|c|c|}
\hline Drinking Water Source & Frequency & Percent & Place for Disposal of Fecal Matter & Frequency & Percent \\
\hline Lake & 42 & 52.5 & Public latrine & 34 & 82.9 \\
\hline Shallow well & 5 & 6.2 & Neighbor's latrine & 4 & 9.8 \\
\hline Piped/tap & 1 & 1.2 & The lake & 1 & 2.4 \\
\hline Spring/river & 5 & 6.2 & The bush & 2 & 4.9 \\
\hline Rainwater & 4 & 5.0 & & & \\
\hline Bore hole & 23 & 28.8 & & & \\
\hline Total & 80 & 100.0 & Total & 41 & 100.0 \\
\hline
\end{tabular}

Table 9. Frequency of Visits by the Fisheries Officer

\begin{tabular}{|l|c|c|}
\hline \multirow{2}{*}{} & \multicolumn{2}{|c|}{ Fisheries Officer } \\
& Frequency & Percent \\
\hline \hline Daily & 2 & 2.8 \\
\hline Weekly & 1 & 1.4 \\
\hline Monthly & 17 & 23.9 \\
\hline Quarterly & 50 & 70.4 \\
\hline Not visited & 1 & 1.4 \\
\hline Total & 71 & 100.0 \\
\hline
\end{tabular}

Table 10. Respondents who had Ever Received Extension Services in Fisheries and Environment

\begin{tabular}{|c|c|c|c|c|}
\hline & \multicolumn{2}{|c|}{ Fisheries Officer } & \multicolumn{2}{c|}{ Environment Officer } \\
\hline & Frequency & Percent & Frequency & Percent \\
\hline \hline Yes & 67 & 94.4 & 24 & 34.3 \\
\hline No & 4 & 5.6 & 46 & 65.7 \\
\hline Total & 71 & 100.0 & 70 & 100.0 \\
\hline
\end{tabular}

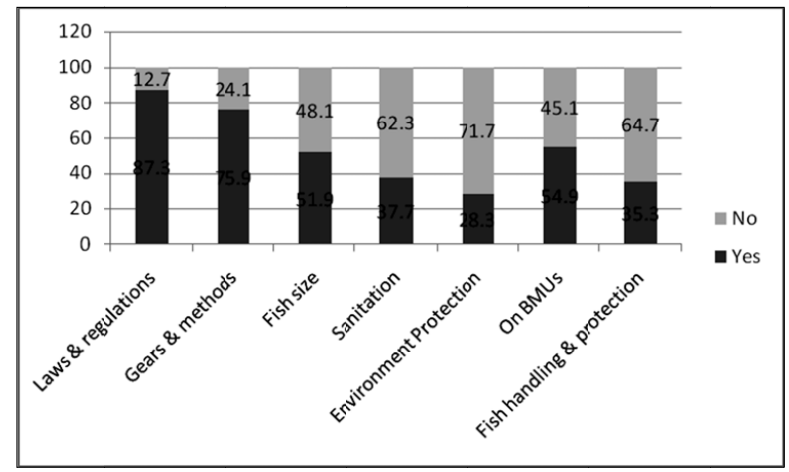

Fig. (7). Respondents who have received information on the different areas of fishing and fisheries management.

fisheries management. It was observed that the majority of the respondents were not members $(92.8 \%, \mathrm{~N}=69)$ of fishermen's or traders' organization whereas $7.2 \%$ responded positively. This was not good for the development of the fisheries. The status of a Beach Management Unit (BMU) at the beach was examined. Most respondents were aware of the presence of BMUs at the beach $(98.6 \%, \mathrm{~N}=69)$, some did not understand the BMU establishment and role. Most of the respondents were members of the BMU $(55.1, \mathrm{~N}=69)$ while the rest $(44.9 \%)$ were not. This was attributed to the lack of understanding of membership and role of BMU. The BMU is responsible for managing all fishery related activities and operations at the beach. The BMU committee comprised of three (3) women representatives, making the $30 \%$ requirement in the BMU guidelines [20]. However, some stakeholders did not fully understand the work of the BMU. The committees and sub committees of the BMU were equally not effective as they only rendered services on voluntary terms. The number of boats and fishing gears owned by the beach community revealed that majority of respondents operated only one boat while the maximum number of boats owned by an individual was 3. On average, an individual owned 9 fishing gears. Among respondents who operated at least one boat, about half of them owned the boats while the rest rented them. The most common type of boats used were the Sesse pointed (Fig. 8).

Almost all the boats were propelled by paddles $(100 \%$, $\mathrm{N}=13$ ). Limited use of the outboard engines was reported. The Nile Tilapia (Oreochromis and Tilapia sp.) were the main fish species targeted (42.9\%), followed by the Silver fish also locally known as Dagaa (Rastreneobola argentea) (38.1\%) while the Nile perch (Lates niloticus) was least targeted $19 \%$. Gear types by number of units were examined and most respondents (50\%) operated gillnets, followed by cast nets $(25 \%)$, small seines $(18.8 \%)$ while $6.2 \%$ used longlines. The time of the year and location when fishing was done was studied. Most respondents operated throughout the year and the distance to their fishing zones was about 3 $\mathrm{km}$. Majority (40\%) of the fishers went fishing in the evening; others went in the morning and at night (Fig. 9). Most fishers who fished in the night mainly targeted the Dagaa fishery.

Majority of the respondents $(55.6 \%)$ revealed that most fish was harvested from shallow (55.6\%) and about $44.4 \%$ from deeper waters. Fishers in deeper waters mainly targeted large-sized tilapia. The fishing in shallow waters may have contributed to the deterioration of fish stocks as fishers targeted breeding and nursery sites along the shores. Fig. (10) presents the main buyers of fish. Local traders supplied mainly to the domestic market. The small proportion of 


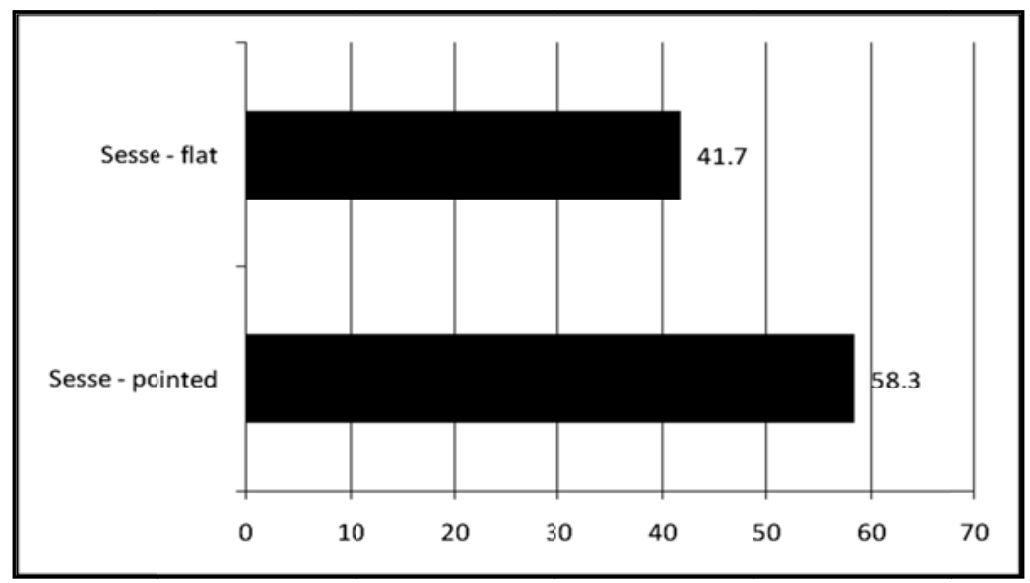

Fig. (8). Types of boats used.

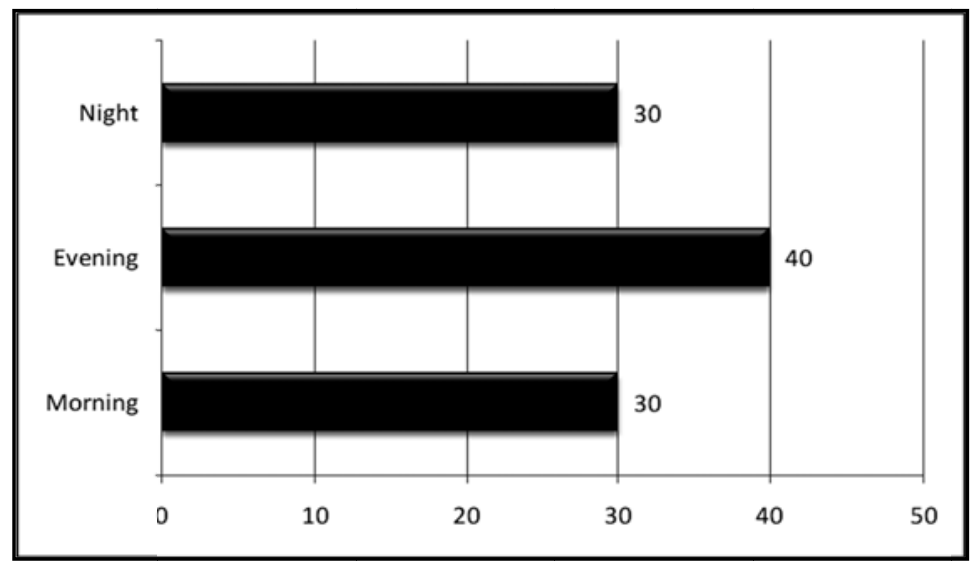

Fig. (9). Distribution of times for fishing.

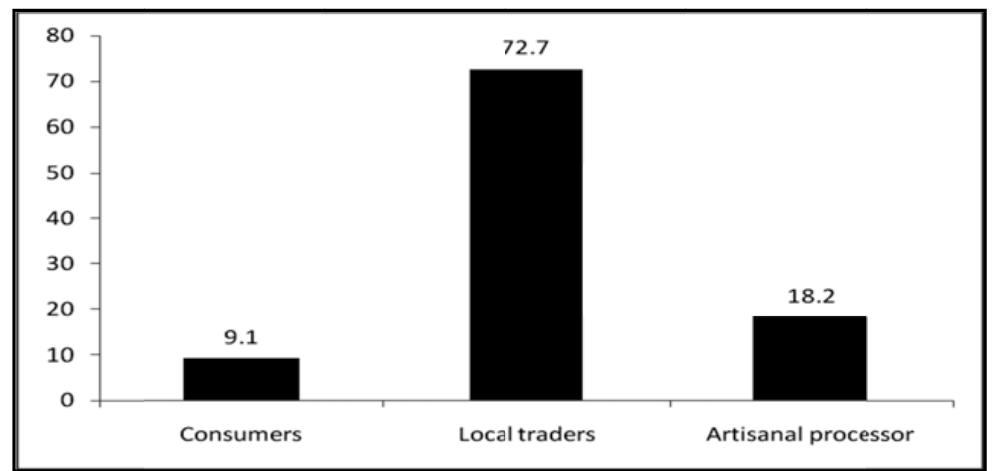

Fig. (10). Respondents' main buyers of fish.

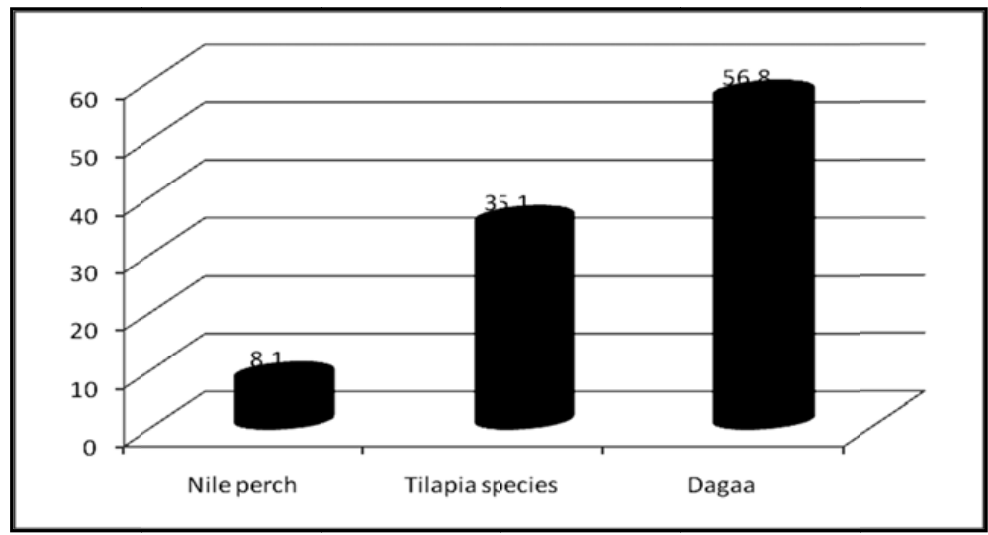

Fig. (11). Fish species targeted during the different months of the year. 
Table 11. Major Activities of Fish Traders and Processors and the Fish Species Processed

\begin{tabular}{|l|c|c|c|c|c|}
\hline \multicolumn{1}{|c|}{ Activity } & Frequency & Percent & Species & Frequency & Percent \\
\hline \hline Processing only & 1 & 4.5 & Nile perch & 1 & 3.4 \\
Trading only & 7 & 31.8 & Tilapia & 7 & 24.1 \\
$\begin{array}{l}\text { Processing and } \\
\text { Trading }\end{array}$ & 14 & 63.6 & Dagaa & 21 & 72.4 \\
\hline Total & 22 & 100.0 & Total & 29 & 100.0 \\
\hline
\end{tabular}

buyers of fish for local market implied that much of the fish was destined for export or to other regions in the country hence leaving the local consumers around the beach with less fish for their own consumption, implying less proteins. The main types of boats were Ssese pointed boats (66.7\%) and 33.3\% were Ssese flat boats. Fig. (11) presents fish species targeted during the different months of the year. Most fishers targeted Dagaa while others targeted tilapia (Oreochromis and Tilapia sp.) and Nile perch (Lates niloticus). The majority of the fishers were involved in processing and trading $(63.6 \%)$ (Table 11). Fish species processed by most respondents was Dagaa, followed by tilapia and then Nile perch.

Majority processed the sun-dried fish $(95.5 \%)$ while the rest opted for fresh fish. It was observed that a limited number of respondents owned drying racks $(7.1 \%)$ while the rest used other methods like mosquito nets $(92.9 \%)$ spread on the ground. All Dagaa processors dried their products on nets. Storage of processed fish was an issue of concern. Most processors/traders stored fish in the house $(81 \%)$, as presented in Table 12. Storage of fish in the house where people lived is not a hygienic practice. Most of the tilapia species were sold in either bags and measured in kilograms or as one whole fish, while Dagaa was mainly sold in plastic basins. Most respondents used other materials like salt and the sun in fish processing $(85.7 \%)$, followed by frying in oil $(14.3 \%)$.

Examination of the status of training in business management among the stakeholders revealed that only $15.8 \%$ ever received training relating to their business. This implied that either there were no effective training programmes $(84.2 \%)$ or the training was not effective. The most relevant training received was on fish processing, by a private firm that trained beach communities in aspects of fish processing a year ago. A few had received some training (17.6\%) in fish quality control. The present study collected information related to sanitation and hygiene at the beach. Although sanita- tion committees were available at the beach, most respondents $(82 \%)$ were not aware of them. Respondents suggested that operationalization of sanitation committees would be the best option $(75.0 \%, \mathrm{~N}=12)$ in handling of sanitation issues, followed by training of the BMU in sanitation issues (25.0\%). Table $\mathbf{1 3}$ presents ways for observing stable fish production at the beach.

\subsection{Focus Group Discussions}

The information collected from questionnaires was complemented by focused group discussions with specialized groups. The major fishery activities at the beach included: fishing, boat ownership, fish trading and processing and boat repairing. Women were mainly involved in fish trading and processing while men dominated the other fishery activities. Other non fishery activities included: livestock and smallholder crop farming and petty trading. The main fish species at the beach were: Tilapia, Dagaa and Nile perch. The Tilapia species was the commonest type of fish five years ago but has now been replaced by Dagaa. This was attributed to safety and security for the gears compared to those for Tilapia. The main fishing equipments were boats, nets, oars and hooks. Gillnets and small seines were among the commonest gear types. A few fishers owned large-sized boats several years ago that targeted fish in deeper waters. However, due to worsening economic conditions, decline in targeted fish species and the rampant theft of gears, these fishers either migrated to other beaches or changed to other activities like petty trading, farming and sand mining.

Many challenges were expressed by the fishers and included the following:

i. theft of fishing gears which is still rampant in the lake

ii. the use of illegal fishing methods and gears. Illegal fishing methods included: beach seining and poison fishing among others while illegal gears included: use of monofilament and mosquito nets.

iii. the poor sanitation and hygiene at the beach. Many fish traders and processors lacked proper fish processing facilities and waste disposal methods. The unhygienic conditions at the beach (dirty and inadequate latrines, poor personal hygiene, and poor waste disposal) increased the susceptibility of fishers to common water-related diseases. These poor hygienic tendencies by fisher communities have been reported elsewhere [7]. Other reported diseases included skin diseases which could have resulted from use of contaminated water [18].

Table 12. Fish Storage Areas and Daily Fish Sales

\begin{tabular}{|c|c|c|c|c|c|c|c|}
\hline \multirow[b]{2}{*}{ In the House } & \multirow{2}{*}{$\begin{array}{c}\text { Frequency } \\
17\end{array}$} & \multirow{2}{*}{$\begin{array}{c}\text { Percent } \\
81.0\end{array}$} & \multirow{2}{*}{$\begin{array}{c}\text { Unit of Measure } \\
\mathrm{Kg}\end{array}$} & \multicolumn{2}{|c|}{ Tilapia } & \multicolumn{2}{|c|}{ Dagaa } \\
\hline & & & & Frequency & Percent & Frequency & Percent \\
\hline Separate store at your home & 2 & 9.5 & Bags & 3 & 66.6 & - & - \\
\hline At the beach & 1 & 4.8 & Basin & 2 & 22.3 & 1 & 5.9 \\
\hline Other & 1 & 4.8 & Others & 1 & 11.1 & 16 & 94.1 \\
\hline Total & 21 & 100.0 & Total & 6 & 100.0 & 17 & 100.0 \\
\hline
\end{tabular}


Table 13. Ways for Observing Stable Fish Production at Beach

\begin{tabular}{|l|c|c|}
\hline & Frequency & Percent \\
\hline \hline Observed fishing regulations & 31 & 52.5 \\
\hline Purchased legal gears & 2 & 3.4 \\
Reported offenders to BMU & 11 & 18.6 \\
\hline Others & 1 & 1.7 \\
\hline None & 14 & 23.7 \\
Total & 59 & 100.0 \\
\hline
\end{tabular}

iv. water quality around the beach had deteriorated as a result of human induced factors such as bathing and defecation directly in the lake leading to increased eutrophication.

v. Sand mining at the beach had caused siltation and migration of some fish species from nearshore areas to deep waters where many fishers could not easily reach.

vi. poverty as the major cause for under-development [21].

vii. ineffective BMU activity, encroachment at the beach by private commercial fish farmers, limited access to financial credit, HIV/Aids risk, poor value addition and marketing among fish traders and processors were reported.

The beach communities developed and recommended an integrated model/system for water quality, health and sanitation management at the beach. The model integrates the technical, capacity building and the legal and institutional aspects as described in Fig. (12).

\section{CONCLUSIONS}

All sites tested positive for total and fecal coliforms. Borehole water had the highest MPN values followed by 10 $\mathrm{m}$ site. This could be attributed to the closeness of sanitary facilities (latrines) to the water points and lakeshore. This situation was further aggravated by the improper wastewater and solid waste disposal methods.

Men dominated every activity in fisheries and the majority was married. Most fishers had attained low education levels. The majority had either only completed primary or had attained but did not complete secondary level education. Majority of fishers were migrants from other places and did not own land. Firewood was their main source of fuel followed by charcoal, explaining the significant deforestation that has resulted into soil erosion and siltation of the lake. The most common diseases suffered by the fishers were malaria, followed by diarrhea and typhoid fever. The main source of drinking water was the lake which exposed people to the risk of infection with water-borne diseases. It was observed that the majority of the beach community did not have latrines and either used the available public latrines or their neighbors' while a few deposited their fecal matter in nearby bushes.

Nile Tilapia (Oreochromis and Tilapia sp.) were the main species targeted followed by the Silver fish, locally known as Dagaa (Rastreneobola argentea) while the Nile perch (Lates niloticus) was least targeted. Most fishing activity was done in shallow waters and this has contributed to the deterioration of fish stocks as fishers targeted breeding and nursery sites along the shoreline. Lack of proper fish storage facilities at the beach was observed as most fish processors/traders who stored fish in their houses hence compromising the quality of the fish. The beach communities developed and recommended an integrated system for water quality, health and sanitation management at the beach.

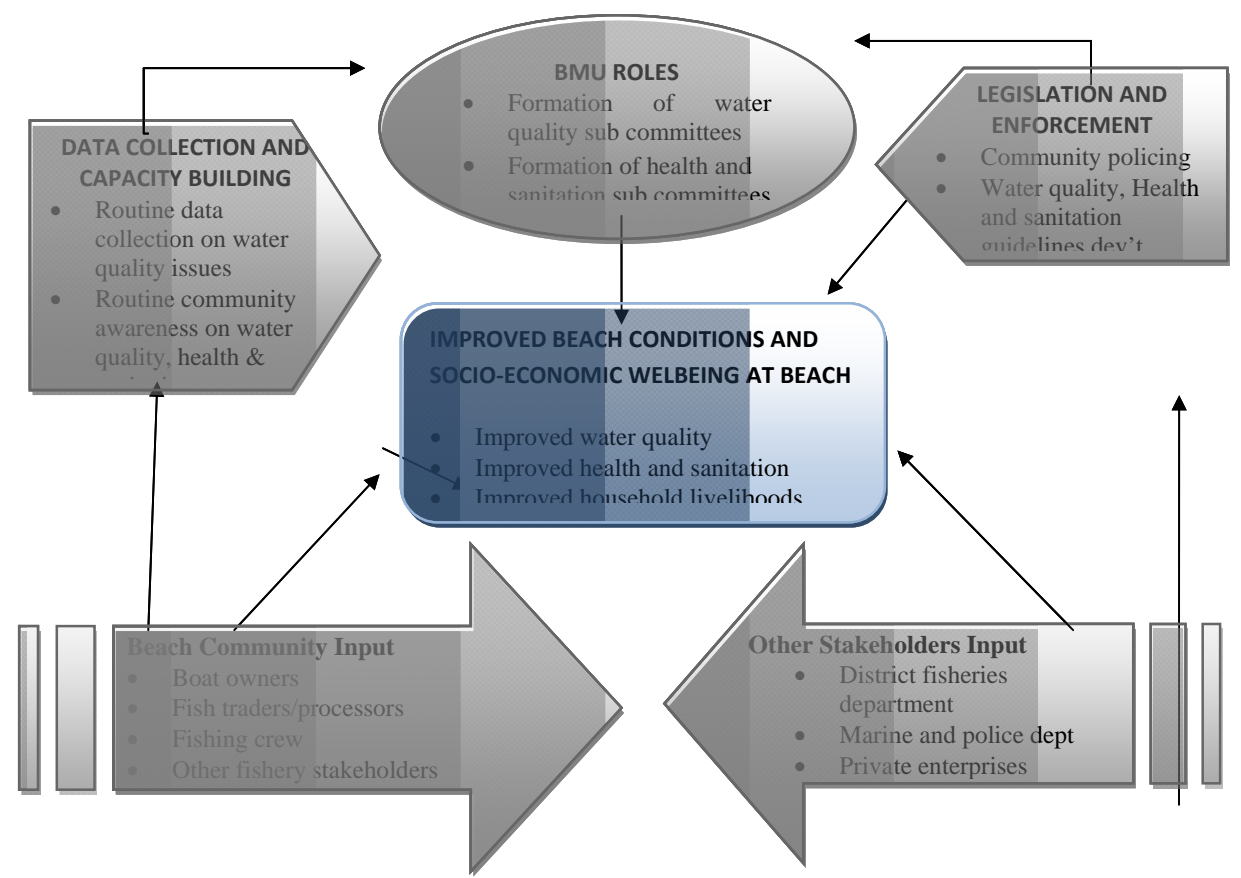

Fig. (12). An integrated model/system for water quality, health and sanitation management for the Beach communities. 
The following recommendations were suggested to be implemented by the fishers themselves at the beach or in partnership with government, private sector and civil society.

1. Development of a concrete and realistic water quality management plan for the beach. The plan would be based on the beach community's priorities that reflect an understanding on economic and social costs of impaired water. The plan would also include the following component:

a) A mechanism for identifying community priorities for water quality management that would guide such efforts at the beach and in neighboring beaches. This would be spearheaded by the proposed water quality management subcommittee of the BMU.

b) A plan for developing a focused and costeffective data collection program for water quality and related uses, as a basis for socioeconomic planning at the beach. The data collection plan should specifically be implemented by fishers and beach community stakeholders.

c) A partnership plan for development of beach level regulations and guidelines for water quality management. The development of the plan should involve fishers, district fisheries staff and other private personnel or entities.

2. Strengthening the presence and capacity of fisheries extension staff at the landing site to work hand in hand with the BMU and the Local Council (LC) system.

3. Periodic monitoring of these socio-economic aspects of the fisheries to be undertaken to evaluate the impacts of fisheries management on the lake.

4. Immediate formation and operationalization of health and sanitation sub committees at the beach with representation from women and all fishery groups.

5. Introduction and operationalization of routine community health and sanitation awareness activities where beach members and communities immediately dependent on the lake to be sensitized on health and sanitation issues.

6. Policing in matters of health and sanitation to improve the health and sanitation situation around the beach. For instance, law breakers would be reported to the health and sanitation sub committees and fined or charged accordingly.

7. BMU and the LC in collaboration with the respective district fisheries department to develop health and sanitation guidelines.

\section{CONFLICT OF INTEREST}

None declared.

\section{ACKNOWLEDGEMENT}

This study was financed by Lake Victoria Research Initiative (VicRes). The Department of Biological Sciences,
Makerere University provided invaluable support. The local communities from within the study area are acknowledged for their invaluable support. Fredrick W. Bugenyi and other experts are acknowledged for reading earlier versions of this manuscript.

\section{REFERENCES}

[1] ILEC: International Lake Environment Committee; Promoting sustainable lake management, Available at: http://www.lakeaccess.org/russ/oxy-gen.htm. [Accessed October 31st, 2011].

[2] P. B. O. Ochumba and D. I. Kibaara, "Observations on blue-green algal blooms in the open waters of Lake Victoria, Kenya", Afr. J. Ecol., vol. 27, pp. 23-34, 1989.

[3] D. Verschuren, T. C. Johnson, H. J. Kling, D. N. Edgington, P. R. Leavitt, E. T. Brown, M. R. Talbot, and R. E. Hecky, "The chronology of human impact on Lake Victoria, East Africa". Proc. R. Soc. London, vol. B269, pp. 289-294, 2002.

[4] H. J. Kling, R. Mugidde and R. E. Hecky, Recent changes in the phytoplankton community of Lake Victoria in response to eutrophication, in Great Lakes of the World: Food webs, health and integrity, Munawar, M. and R. E. Hecky, Eds. Backhuys: Leiden, 2001, pp. 47-66.

[5] J. F. Talling and J. Lemoalle, Ecological dynamics of tropical inland waters, Cambridge Univ Press: UK, 1998.

[6] F. J. Muyodi, and R. E. Hecky, Water quality synthesis report for Uganda. Water Quality and Ecosystem Management, LVEMP, Ministry of Water and Environment, Republic of Uganda, World Bank, 2005.

[7] F. J. Muyodi, R. E Hecky, J. M. Kitamirike and R. Odong, "Trends in health risks from water-related diseases and cyanotoxins in Ugandan portion of Lake Victoria basin", Lakes and Reservoirs: Res. Manag. vol. 14, pp. 247-257, 2009.

[8] B. W. Ksoll, S. Ishii, J. M. Sadowsky and E. R. Hicks, World Bank, 1996. Staff Appraisal Report for Lake Victoria Environmental Management Project. Report No. 15541-AFR, 1996.

[9] F. J. Muyodi, F. L. Mwanuzi and R. Kapiyo, "Environmental quality and fish communities in selected catchments of Lake Victoria", Open Environ. Eng. J., vol. 4, pp. 54-65, 2011.

[10] APHA/AWWA/WEF, Standard Methods for the Examination of Water and Wastewater, 20th ed.: United Book Press Inc.: Baltimore, Maryland, 1998.

[11] M. Medard, K. O. Odongkara and R. O. Abila, Report on the status of socio-economic research and monitoring on Lake Victoria. Lake Victoria Fisheries Organization, Jinja, Uganda, 2004.

[12] L. D. Morgan, Focus Groups as Qualitative Research, Sage Publications: London, 1988.

[13] R. E. Hecky, H. A. Bootsma, R. Mugidde and F. W. B. Bugenyi, "Phosphorus pumps, nitrogen sinks, silicon drains: plumbing nutrients in the African Great Lakes", In: T. C. Johnson and E. Odada, Eds, The limnology, climatology and paleoclimatology of the East African lakes, Gordon and Breach Publishers: Amsterdam, Netherland, 1996, pp. 205-224.

[14] J. S. Balirwa, "Lake Victoria wetlands and the ecology of the Nile Tilapia, Oreochromis niloticus L.", Ph.D. thesis, Agricultural University of Wageningen, The Netherlands, 1998.

[15] L. M. Campbell, J. S. Balirwa, Dixon, D. G. and R. E. Hecky, "Biomaginification of Mercury in fish from Thruston Bay, Napoleon Gulf, Lake Victoria (East Africa)", African J. Aquat Sci. vol. 29(1), pp. 91-96, 2004.

[16] G. Fryer, "The Lake Victoria Fisheries: Some facts and fallacies", Biol. Conserv., vol. 5, pp. 305-308, 1973.

[17] F. J. Muyodi, F. W. B. Bugenyi and R.E Hecky, "Experiences and Lessons Learned from Interventions in the Lake Victoria basin: the Case of Lake Victoria Environmental Management Project", Lakes Reservoirs: Res. Manag., vol. 15, pp. 77-88, 2010.

[18] R. O. Abila, M. Medard and K. O. Odongkara, Implementation plan for socio-economic research and monitoring. Lake Victoria Fisheries Organization, Jinja, Uganda, 2004.

[19] LVEMP (Lake Victoria Environmental Management Project), 1998: Technical Report on Lake Victoria Wider Socio-Economic Program Management of the World's Lakes and Reservoirs, Available at: http://www.ilec.or.jp/database/afr/afr-05.html. [Accessed October 17th, 2011] 
[20] N. Nyega, R. Y. M. Kangalawe and H. L. Kiwasila, "Beach management units in Lake Victoria: Assessment of their effectiveness in managing fisheries resources in Ilemela district, Tanzania", ISBN 978-3-8443-9930-1, Lap Lambert Academic Publishing,
[21] K. O. Odongkara, "Poverty in the fisheries: indicators, causes and interventions for Lake Victoria, Uganda". LVEMP Research Report, Jinja, Uganda, 2001.

(c) Muyodi and Kapiyo; Licensee Bentham Open.

This is an open access article licensed under the terms of the Creative Commons Attribution Non-Commercial License (http://creativecommons.org/licenses/by-nc/3.0/g) which permits unrestricted, non-commercial use, distribution and reproduction in any medium, provided the work is properly cited. 